\title{
Influence of Laser Welding Aluminium Alloy on Mechanical Properties of Welded Joints
}

Miroslav Sahul, Milan Turňa, Jana Šugárová, Martin Sahul

Slovak University of Technolgy in Bratislava, Faculty of Materials Science and Technology, Bottova 25, 91724 Trnava, Slovakia. miroslav.sahul@ stuba.sk

Paper deals with the analysis of aluminium alloy welded joints produced by disk laser. Naturally hardenable Al alloy type AW 7075, $2.5 \mathrm{~mm}$ in thickness was suggested as welded material. Welded joints were produced by use of disk laser type TruDisk 4002 with $1.03 \mu \mathrm{m}$ wavelength and maximum power $P=2.0 \mathrm{~kW}$. Welded joints were fabricated with different parameters. Laser power varied within interval from 1.6 to $1.7 \mathrm{~kW}$ and welding speed was invariable $30 \mathrm{~mm} / \mathrm{s}$. Welding was performed without the use of filler metal. Laser light cable in diameter $\emptyset$ $400 \mu \mathrm{m}$ (spot diameter $\emptyset 748 \mu \mathrm{m}$ ) was used. Welding was performed with Ar shielding gas with $10 \mathrm{l} / \mathrm{min}$ flow rate. Also root protection was provided with an inert gas (Ar). The focal length was $f=200 \mathbf{~ m m}$. Laser beam was focused under the surface of welded material. Evaluation of fabricated welds was carried out by use of light microscopy, microhardness measurement across the boundary of welded joints and static tensile test.

Keywords: laser welding, disk laser, aluminium alloy AW 7075, natural aging, quality control of welds

\section{Acknowledgement}

The paper was prepared under the support of Grant Agency VEGA of the Ministry of Education, Science, Research and Sport of the Slovak Republic and Slovak Academy of Sciences, projects No. 1/2594/12 and 1/1035/12.

\section{References}

[1] PALEOCRASSAS, A. G., TU, J. F. (2007). Low-Speed Laser Welding of Aluminum Alloy 7075-T6 Using a 300W, Single-Mode, Ytterbium Fiber Laser. Welding Journal. Vol. 86, pp. 179 - 186

[2] RAJAKUMAR, S. et al. (2011). Influence of Friction Stir Welding Process and Tool Parameters on Strength Properties of AA7075-T6 Aluminium Alloy Joints. Materials \& Design. Vol. 32, Issue 32, pp. 535 - 549.

[3] HU, B., RICHARDSON, I. M. (2006). Hybrid Laser/GMA Welding Aluminium Alloy 7075. Welding in the World. Vol. 50, No. 7/8

[4] GOLOBORODKO, A. et al. (2004). Friction Stir Welding of a Commercial 7075-T6 Aluminum Alloy: Grain Refinement, Thermal Stability and Tensile Properties. Materials Transactions. Vol. 45, No. 8, pp. 2503 - 2508.

[5] SIVASHANMUGAM, M. et al. (2009). Investigation of Microstructure and Mechanical Properties of GTAW and GMAW Joints of AA7075 Aluminium Alloy. International Journal on Design and Manufacturing Technologies. Vol. 3, No. 2, pp. 56 - 62.

[6] MOTOHASHI, Y. et al. (2008). Grain Refinement Process in Commercial 7075-T6 Aluminum Alloy under Friction Stir Welding and Superplasticity. Materialwissenschaft und Werkstofftechnik. Vol. 39, No. 4-5, pp. 275-278.

[7] ISADARE, A. D. et al. (2013). Effect on Heat Treatment on Some Mechanical Properties of 7075 Aluminium Alloy. Materials Research. Vol. 16, pp. 190 - 194.

[8] LIU, CH., NORTHWOOD, D. O., BHOLE, S. D. (2004). Tensile Fracture Behaviour in $\mathrm{CO}_{2}$ Laser Beam Welds of 7075-T6 Aluminium Alloy. Materials \& Design. Vol. 25, pp. 573 - 577.

[9] BALASUBRAMANIAN, V. et al. (2008). Influences of Pulsed Current Welding and Post Weld Aging Treatment on Fatigue Crack Growth Behavior of AA7075 Aluminium Alloy Joints. International Journal of Fatigue. pp. 405 $-416$.

[10] VENUGOPAL, T. et al. (2004). Studies on Friction Stir Welded AA 7075 Aluminium Alloy. Transactions of the Indian Institute of Metals. Vol. 57, No. 6, pp. 659-663.

[11] WU, S. C. et al. (2013). Porosity, Element Loss and Strength Model on Softening Behaviour of Hybrid Laser Arc Welded Al-Zn-Mg-Cu Alloy with Synchrotron Radiation Analysis. Welding Journal. Vol. 92, pp. 64 - 71.

[12] TEMMAR, M. et al. (2011). Effect on Post Weld Aging Treatment on Mechanical Properties of Tungsten Inert Gas Welded Low Thickness 7075 Aluminium Alloy Joints. Materials and Design. Vol. 32, pp. 3532 - 3536.

[13] KOVANDA, K., HOLUB, L., KOLAŘíK, L., KOLAŘíKOVÁ, M., VONDROUŠ, P. (2012). Experimental Verification of FEM Simulation of GMAW Bead on Plate Welding. Manufacturing Technology. Vol. 12, No. 12, pp. 30 - 33. ISSN 1213-2489. 
[14] PODREZ-RADZISZEWSKA, M. (2011). Weldability Problems of the Technical AW 7020 Alloy. Manufacturing Technology. Vol. 11, No. 11, pp. 59 - 66. ISSN 1213-2489.

[15] KOLAŘÍKOVÁ, M., KOLAŘÍK, L., KOVANDA, K., HRABINA, R. (2013). Welding of Normalized Heat Treated Steels S355NL Large Thicknesses by Method FCAW. Manufacturing Technology. Vol. 13, No. 2, pp. 181 - 188. ISSN 1213-2489. 